\title{
CRITICAL FACTORS AFFECTING SUCCESS OF A BLAST FURANCE PROJECT
}

\author{
Potti Srinivasa Rao ${ }^{1}$ Shiva Prasad H C ${ }^{2}$ Gopalkrishna B ${ }^{3}$ \\ 1,2,3 Department of Humanities and Management, Manipal University \\ MIT Manipal, India \\ ${ }^{1}$ srinivasapotty@yahoo.co.in \\ ${ }^{2}$ hcs.prasademanipal.edu \\ ${ }^{3}$ gopalkrishna.b@manipal.edu
}

\begin{abstract}
The project management is a subsection of operational management that links to an economic activity. This emphasizes the process of making decisions and operationalising the strategies and tactics to reach the goal through owners, contractors, engineers and consultants within the planned constraints via meeting the schedule. Critical success factors are the bottom line for the successful completion while countering the factors of failure. This research study mainly focuses on relining of blast furnace as a project and so as to identify the critical success factors that influence the project success in a private steel manufacturing company in India.

Blast furnaces experience stress in terms of thermal, physical and ware characteristics causing deterioration of the interior blasting architecture. These deformational effects are mitigated through periodic maintenance. The deformation caused by mechanical properties needs to replacement of the lining termed as relining of the shell. Variables for the critical success factors were operationalised through questionnaire survey to identify the critical success factors. Data were collected and evaluated by statistical methods to identify the most critical success factors that influence the project success. The results reveals that project manager related factors are the most important critical success factor for a blast furnace relining project. By taking the critical success factors as important key inputs and fine tuning these factors in such a way project time and cost are saved.
\end{abstract}

\section{KEYWORDS}

Critical success factors, project manager, communication, criticality index, project experience

\section{INTRODUCTION}

Project planning and scheduling is an important routine activity for many types of companies. A project without the work schedule is less meaningful. At the same time there are variables that intervene the project success. Every project is packed with intrinsic complexity, uncertainty and dynamics. Decisions taken to achieve the targeted milestones are the indicators in anticipation the expected outcomes and thus monitoring the work-in-progress [12]. Research evidences show that certain variables are monitored to crib the success and there not a single definite factor that can cause the project delay. Identification of casual critical factors for project delay is researched frequently and it is essential [8]. Critical factors are those key factors and are the activity in that favours the target the success [9]. Rockart [1982] termed 'Critical Success Factors (CSF)' as those factors of key areas of activity that directly gives favourable results for a project goal. Project success requires creating a well-planned project schedule as well as understanding of the key success factors also. It helps the project manager and the stakeholders

DOI : 10.14810/ijmech.2014.3205 
to take the right decisions and act towards the project success.

\subsection{Background Theory and Literature Review}

Project management in simple terms includes planning, organizing, and managing of tasks and resources to accomplish a defined objective, usually with constraints on time cost and quality. A plan can be simple as a list of tasks and their scheduled start and finish dates written on notepad. A complex plan on the other hand, might deal with thousands of tasks and resources and a project budget. Summarily the project plan is shares elements, such as disintegrating the project into manageable tasks, scheduling the tasks and then tracking tasks as the work progresses. Any project has three phases to follow (a) planning the project and creating a schedule-defining the tasks and their durations, setting up relationships between tasks and assigning resources, (b) managing changes in the project as the process follows the schedule and tracking the schedule as the project progresses,(c) communicating project information-clients, project staff, and management look for information.

The origin of modern project management roots from the chemical industry just prior to World War II. Forwarding its focus on planning and scheduling, managing budget and evaluating quality has been the main focus of project management practice, research and development [15]. The project success depends on interfacing with clients and stakeholders objectives [6]. Project management success is oriented towards planning and control in the context of the short term life of the project development and delivery but project success tends to be long term in nature and stretches with the objective or product, the project delivers [1]. Any project management's success and project success are being measured against the traditional gauges of performance with reference to time, cost and quality/performance [16]. Successful factors are the guiding steps to attain the project goal. The relative importance on CSFs varied over the course the project life cycle [6]. Most popular CSF' accepted by research community are-project mission, top management support, project schedule/plan, client consultation, personnel, technology to support the project, client acceptance, monitoring and feedback, channels of communication, troubleshooting expertise[15, 16]. A holistic CSF framework was designed to classify the individual success factors and corporate/industrial factors that include factors related to the project, factors related to the project manager and team, factors related to the organization and factors related to the external environment [17]. The schemas of systematic analysis on CSF were to identify the relationships and implications. Such a study has shown that CSFs vary with industry and that top management support.

The success factors were grouped into; project management factors, procurement related factors, client-related factors, design team-related factors, contractor related factors, project manager related factors, business and work environment related factors. This research study identified a list of specific factors toward criticality and formed the construct to decision making effectiveness, project Manager's experience, contractor's cash flow, contractor experience, timely decision by owner/ owner's representative, site management, supervision, planning effort, prior project management experience and client's ability to make decision[13]. During recent times group of researchers have identified the delaying factors as counter intuitive to success and were grouped as-delay factors relevant to clients, delay factors relevant to consultants, delay factors relevant to contractors, delay factors relevant to contract firm, delay factors relevant to labour, delay factors relevant to project conditions and external delay factors. The finding indicate that the majority of delay factors are relevant to client factor. It is concluded that for reducing the delay client must have strong economical ability, financial arrangement for project and timely decision. The role project manager as a project participant has a direct link to monitoring the critical factors with findings their involvement and commitment of as a project participant play a vital role in the project performance [5]. Some of the factors were also studied in manufacturing industries with original framework developed 
Pinto(1982) and investigated two major dimensions of project success, the first dimension is success measured by the impact on the end user or clients. The second dimension is success measured by the impact on the organization and a clear project mission is positively related to both direct and indirect project success [3].

\section{Factors Considered For The Project Success}

Number of factors that influence the success of project implementation has been identified in different literature. Literature support that grouping of CSFs help to go for second order factors and thus grouping with seven main factors which include- (a) project management factors, $(b)$ procurement-related factors, (c) client-related factors, (d) design team-related factors, (e) contractor-related factors, $(f)$ project manager-related factors, and $(g)$ business and work environment-related factors

(a) Project Management Factors: project management action is a key for project success with the management tools, the project managers would be able to plan and execute their construction projects to maximize the chances of project's success. The variables in project management include top management support, feedback capabilities, coordination effectiveness, decision making effectiveness, monitoring, planning effort, risk identification control of subcontractor's works, and finally the overall managerial actions [7].

(b) Procurement Related Factors: researchers have identified the importance of procurement factors and it is defines the scope of procurement as the framework within which construction is brought about, acquired. Therefore, two attributes are used to measure this factor; they are procurement method (selection of the organization for the design and construction of the project) and tendering method (procedures adopted for the selection of the project team and in particular the main contractor) [10].

(c) Client-Related Factors: this defines the project participants as the key players, including project manager, client, contractor, consultants, subcontractor, supplier, and manufacturers. The importance of client and client's representative is a significant factor on construction time. The client related factors concerned with client experience, knowledge of construction project organization, client confidence in the construction team, well-defined scope, owner's risk attitude, client project management [4] [11].

(d) Design Team Related Factors: Designers play a vital role as their work involves from inception to completion on a project as it is considered that design team-related factors depends on design team experience, project design complexity, and mistakes/delays in producing design documents [10].

(e) Contractor Related Factors: The main contractor and subcontractors take responsibility as the project reaches the construction stage. The variables include contractor experience, site management, supervision and involvement of subcontracting, contractor's cash flow, effectiveness of cost control system, and speed of information flow [10].

(f) Project Manager Related Factors: The project manager is another key stakeholder in a construction project and definitely depends on the competence of the manager. While it becomes a critical factor by affecting project planning, scheduling, and communication. This factor composite on skills, knowledge and characteristics of project manager's commitment, competence, experience, and authority. Team effort by all parties to a contract-owner, architect, construction manager, contractor, and subcontractors-is a crucial 
ingredient for the successful completion of a project [4][17].

(g) Business And Work Environment Related Factors: research evidence supports the environmental factor on project success. External environment influences the construction process such as social, political, and technical systems. The attributes used to measure this factor are economic environment, social environment, political environment, physical environment, industrial relation environment, and level of technology advanced [2][4].

\section{MeTHODOLOGY}

The study is carried out in a private steel manufacturing unit named as Pesa Industries Ltd. (pseudo name) in India. It is one of the largest private sector iron ore producer and exporter, with mining and processing facilities at various locations in India. It currently has access to 240 million metric tons (MT) reserves and resources of iron ore.

Seven factors were operationalised as CSFs were grouped and identified from the background theory and literature in the field of project management and critical success factors a questionnaire method is taken from a standardized questionnaire [13].

3.1. Questionnaire administration: The questionnaire has two parts; the part A contains the list of factors to be ranked as to make project success factors on ranked scale 1 to 7 . The part B of questionnaire has items from the research 'Assessment of critical success factors for construction projects. The survey questionnaire by the researcher, briefing about the objective of the study was handed over to 89 participants, including both the employees of the Sesa Industries Ltd. and the contractors involved in the project. The participants were asked to rank the variables on a dipole scale of 1 to 10 , were 10 is being the highest rank and one is having the lowest rank towards the success of a project. Part B contains the demographic questions about the respondents. The analysis of the survey was done using the SPSS $15.0 \mathrm{v}$ and AMOS $16.0 \mathrm{v}$ software's. The descriptive analysis, reliability tests using Cronbach's alpha were computed. To identify the criticality index for each factor and criticality index for factor following Table 1 depict the methodology for deciding the critical factor index.

Table 1. Criticality indexes based on mean factor score.

\begin{tabular}{|l|c|l|}
\hline $\begin{array}{l}\text { Mean Factor } \\
\text { Score Range }\end{array}$ & $\begin{array}{c}\text { Criticality } \\
\text { Index }\end{array}$ & \multicolumn{1}{c|}{ Criticality Level } \\
\hline $1.0-2.5$ & 1 & Least significant towards project success. \\
\hline$>2.5-5$ & 2 & Mildly significant towards project success. \\
\hline$>5.0-7.5$ & 3 & Moderately significant towards project success. \\
\hline$>7.5-10$ & 4 & Most significant towards project success. \\
\hline
\end{tabular}

Analysing the errors in the feedback latent variable structural equation modelling is used to test the latent variables loading on the factors that have emerged in the first stage. The correlation, reliability, and path analysis of the success factors is done.

\section{RESULTS}

The questionnaire survey was conducted by meeting the participants individually and asked them to rank the factors. The questionnaire was distributed to 89 people in whom 63 (71\% response rate) people responded. All the participants were directly and indirectly involved in some or the other projects where the research is carried. The gender ratio in the questionnaire survey of the total respondents $93 \%$ are males and only $7 \%$ of the respondents were females, 
having age distribution of the mean of the maximum of the youngest group was 25 years. The average age of the participants is 33 years among them younger group belonged with not less than 20 years of age and not later than 60 years. The participants surveyed in this research with different level and position within the organization included contractors, regular employees on the role. It was found that $36 \%$ are senior engineers, $32 \%$ are managers, $13 \%$ senior managers, $11 \%$ of them are contractors and rest $8 \%$ constituted clerks and others. It is observed that participants had below 10 years of experience either in the neither same organization nor elsewhere. About $59 \%$ of them belong to this category. The senior most experienced personals are only five percentages. The respondent preferences and perception on their identified success factors affecting the project success and their mean and mode extracted are indicated (refer to Table 2).

Table 2. The Success Factors and their mean and mode

\begin{tabular}{|c|c|c|}
\hline Success Factors & Mean & Mode \\
\hline \multicolumn{3}{|l|}{ Project Management Related Factors } \\
\hline Project monitoring & 8.11 & 10 \\
\hline Control of subcontractors work & 7.27 & 9 \\
\hline feedback capabilities & 6.41 & 6 \\
\hline Planning effort & 7.89 & 10 \\
\hline Co-ordination effectiveness & 7.54 & 7 \\
\hline Decision making effectiveness & 7.97 & 10 \\
\hline Risk identification \& allocation & 6.92 & 8 \\
\hline Top management support & 7.75 & 10 \\
\hline \multicolumn{3}{|l|}{ Organizational Related Factors } \\
\hline Owner's knowledge of project management & 7.62 & 8 \\
\hline Owner's confidents in contractors & 7.16 & 8 \\
\hline Owner's clear \& precise definition of project scope \& objectives & 7.60 & 9 \\
\hline Owner's risk attitude & 6.81 & 8 \\
\hline Owner's emphasis on low construction cost & 6.05 & 6 \\
\hline Owner's ability to make decision & 7.75 & 10 \\
\hline Owner's previous experience in project & 7.37 & 9 \\
\hline Size of the organization & 5.44 & 9 \\
\hline $\begin{array}{l}\text { Coordination among the employees in the organization (absence of } \\
\text { politicking) }\end{array}$ & 6.83 & 8 \\
\hline Coordination among project team & 7.83 & 9 \\
\hline \multicolumn{3}{|l|}{ Procurement Related Factors } \\
\hline Identification of scope of procurement & 7.97 & 10 \\
\hline Relationship b/w technical team and purchase team & 8.00 & 9 \\
\hline Emphasis on cost reduction & 6.92 & 7 \\
\hline Timely bidding & 8.06 & 9 \\
\hline Previous experience with the contractor & 7.62 & 8 \\
\hline \multicolumn{3}{|l|}{ Design Related Factors } \\
\hline Design team's experience & 8.51 & 9 \\
\hline Project design complexity & 7.43 & 8 \\
\hline Mistakes/delays in producing design documents & 7.76 & 9 \\
\hline Ability to make clear and precise drawings & 8.40 & 9 \\
\hline \multicolumn{3}{|l|}{ Contractor Related Factors } \\
\hline Contractors experience & 8.43 & 8 \\
\hline Site management & 7.98 & 8 \\
\hline Extend (Involvement) of subcontracting & 6.62 & 7 \\
\hline Contractor's cash flow & 7.44 & 7 \\
\hline Speed of information flow b/w owner \& contractor & 7.52 & 9 \\
\hline Knowledge of workers in the work & 7.25 & 8 \\
\hline Relationship b/w owner \& contractor & 7.08 & 9 \\
\hline Use of advanced technology \& equipment's in construction & 7.25 & 10 \\
\hline \multicolumn{3}{|l|}{ Project Manager Related Factors } \\
\hline PM's competence & 8.13 & 8 \\
\hline PM's experience & 7.98 & 9 \\
\hline
\end{tabular}




\begin{tabular}{|c|c|c|}
\hline PM's authority to take day to day decisions & 7.85 & 9 \\
\hline PM's authority to take financial decisions, selecting key team members & 7.51 & 9 \\
\hline PM's Technical capability & 7.43 & 9 \\
\hline PM's leadership skills & 7.82 & 10 \\
\hline Coordinating ability of PM with contractors & 7.08 & 8 \\
\hline Coordinating ability of PM with top management & 7.21 & 8 \\
\hline PM's confidence on the team members & 7.51 & 8 \\
\hline \multicolumn{3}{|l|}{ Business Related Factors } \\
\hline Economic environment & 7.46 & 8 \\
\hline Social environment & 6.86 & 9 \\
\hline Political environment & 6.10 & 9 \\
\hline Commitment of all parties to the project & 7.30 & 8 \\
\hline Adequacy of funding & 7.80 & 9 \\
\hline Technology availability & 7.72 & 9 \\
\hline Human skill availability & 8.02 & 9 \\
\hline
\end{tabular}

The results from Table 2 and taking into the consideration of criticality assessment criteria (refer Table 1), the factors are ranked in descending order of criticality, and the top 10 critical success factors are as given in Table 3 .

Table 3. Grouping of CSF- various factors

\begin{tabular}{|l|l|l|l|l|}
\hline Sl.no. & Success factor & $\begin{array}{l}\text { Factor } \\
\text { Categorized }\end{array}$ & $\begin{array}{l}\text { Mean Criticality } \\
\text { index }\end{array}$ & $\begin{array}{c}\text { Criticality } \\
\text { ranking }\end{array}$ \\
\hline 1 & Design team's experience & Desig. & 8.51 & 4 \\
\hline 2 & Contractors experience & Contra. & 8.43 & 4 \\
\hline 3 & Ability to make clear and precise drawings & Desig. & 8.40 & 4 \\
\hline 4 & PM's competence & P.Mngr. & 8.13 & 4 \\
\hline 5 & Timely bidding & Procu. & 8.06 & 4 \\
\hline 6 & Human skill availability & Busi. & 8.02 & 4 \\
\hline 7 & Relationship b/w technical and purchase team & Procu. & 8.00 & 4 \\
\hline 8 & PM's experience & P.Mngr. & 7.98 & 4 \\
\hline 9 & Site management & Contra. & 7.98 & 4 \\
\hline 10 & Identification of scope of procurement & Procu. & 7.97 & 4 \\
\hline
\end{tabular}

Based on a value of mean criticality index for each category the earlier identified success factor criticality has been arranged in descending order of criticality.

Table 4. Mean criticality index in descending order of criticality

\begin{tabular}{|c|l|c|c|}
\hline Sl. no. & \multicolumn{1}{|c|}{ Category } & $\begin{array}{c}\text { Criticality } \\
\text { index }\end{array}$ & $\begin{array}{c}\text { Criticality } \\
\text { ranking }\end{array}$ \\
\hline 1 & Design related factors & 8.02 & 4 \\
\hline 2 & Procurement related factors & 7.71 & 4 \\
\hline 3 & Project manager related factors & 7.61 & 4 \\
\hline 4 & Project management related factors & 7.48 & 3 \\
\hline 5 & Contractor related factors & 7.45 & 3 \\
\hline 6 & Business \& Environment related factors & 7.31 & 3 \\
\hline 7 & Organizational related factors & 7.04 & 3 \\
\hline
\end{tabular}

The Reliability of the instruments used was done by calculating the Cronbach's alpha. The result (Ref. Table 5) shows that the value of Cronbach's alpha is greater than 0.65 for all the factors categories indicating the variables in each factor category are reliable [14]. Through the correlation matrix it was found that project manager has highest influence on the methods of managing the project. The project manager decides to monitor the project and aims at measuring the progress of the project. Whereas the feedback from project management related factors helps the project manager in decision making and communication among the stakeholders. 
International Journal of Recent advances in Mechanical Engineering (IJMECH) Vol.3, No.2, May 2014

Table 5. Correlation matrix

\begin{tabular}{|c|c|c|c|c|c|c|c|c|c|c|}
\hline \multirow{2}{*}{ Category } & \multirow{2}{*}{ Items } & \multirow{2}{*}{ Mean } & \multirow{2}{*}{ S.D } & \multirow{2}{*}{$\begin{array}{c}\text { Cronbach } \\
\text { ' } \alpha \text { ' }\end{array}$} & \multicolumn{6}{|c|}{ Correlation matrix } \\
\hline & & & & & P. Mgnt. & Orga. & Procu. & Desig. & Contra. & P. Mgr. \\
\hline P. Mgnt. & 8 & 7.49 & 1.18 & .76 & 1 & & & & & \\
\hline Orga. & 10 & 7.05 & 1.24 & .75 & $.72 * *$ & 1 & & & & \\
\hline Procu. & 5 & 7.71 & 1.33 & .65 & $.60 * *$ & $.66^{* *}$ & 1 & & & \\
\hline Desig. & 4 & 8.02 & 1.33 & .73 & $.49 * *$ & $39 * *$ & $.45^{* *}$ & 1 & & \\
\hline Contra. & 8 & 7.45 & 1.57 & .77 & $.67 * *$ & $.70 * *$ & $.64 * *$ & $.53 * *$ & 1 & \\
\hline P. Mgr. & 9 & 7.62 & 1.50 & .88 & $.82 * *$ & $.70 * *$ & $.50 * *$ & $.48 * *$ & $.76 * *$ & 1 \\
\hline Busi. & 7 & 7.31 & 1.34 & .80 & $.61 * *$ & $.57 * *$ & $.50 * *$ & $.47 * *$ & $.60 * *$ & $.68 * *$ \\
\hline
\end{tabular}

${ }^{* * *} \mathrm{p} \leq 0.001, * * \mathrm{p} \leq 0.01,{ }^{*} \mathrm{p} \leq 0.1$

All the success factors are measured against each category by path analysis. The regression weight is calculates o identify the critical ratio. The critical ratio of each factors are significance with $p>0.1$.

Table 6. Success factor significant path coefficient

\begin{tabular}{|c|c|c|c|c|c|}
\hline Sl.No. & Success Factor & Category & Estimate & S.E. & C.R. \\
\hline 1 & Project monitoring & P. Mgt. & 1 & & \\
\hline 2 & Control of subcontractors work & P. Mgt. & 0.883 & 0.298 & $2.957 * *$ \\
\hline 3 & Feedback capabilities & P. Mgt. & 1.374 & 0.395 & $3.475 * * *$ \\
\hline 4 & Planning effort & P. Mgt. & 1.224 & 0.366 & $3.342 * * *$ \\
\hline 5 & Co-ordination effectiveness & P. Mgt. & 0.969 & 0.3 & $3.231 * * *$ \\
\hline 6 & Decision making effectiveness & P. Mgt. & 0.845 & 0.293 & $2.881 * *$ \\
\hline 7 & Risk identification \& allocation & P. Mgt. & 0.868 & 0.328 & $2.648 * *$ \\
\hline 8 & Top management support & P. Mgt. & 0.899 & 0.33 & $2.723 * *$ \\
\hline 9 & Owner's knowledge of project management & Orga. & 1 & & \\
\hline 10 & $\begin{array}{l}\text { Owner's clear \& precise definition of project scope } \& \\
\text { Objectives }\end{array}$ & Orga. & 1.057 & 0.463 & $2.283^{*}$ \\
\hline 11 & Owner's risk attitude & Orga. & 0.874 & 0.412 & $2.121^{*}$ \\
\hline 12 & Owner's emphasis on low construction cost & Orga. & 1.11 & 0.543 & $2.044 *$ \\
\hline 13 & Owner's ability to make decision & Orga. & 1.128 & 0.471 & $2.394 *$ \\
\hline 14 & Owner's previous experience in project & Orga. & 1.361 & 0.555 & $2.451^{*}$ \\
\hline 15 & Size of the organization & Orga. & 0.661 & 0.508 & $1.303^{*}$ \\
\hline 16 & $\begin{array}{l}\text { Co-ordination among employees in the organisation } \\
\text { (without politicking) }\end{array}$ & Orga. & 2.027 & 0.696 & $2.914 * *$ \\
\hline 17 & Coordination among project team & Orga. & 1.979 & 0.688 & $2.878 * *$ \\
\hline 18 & Owner's confidents in contractors & Orga. & 1.184 & 0.576 & $2.056^{*}$ \\
\hline 19 & Identification of scope of procurement & Procu. & 1 & & \\
\hline 20 & Relationship b/w technical team and purchase team & Procu. & 0.685 & 0.167 & $4.098 * * *$ \\
\hline 21 & Emphasis on cost reduction & Procu. & 0.377 & 0.204 & $1.848^{*}$ \\
\hline 22 & Timely bidding & Procu. & 0.685 & 0.162 & $4.229 * * *$ \\
\hline 23 & Previous experience with the contractor & Procu. & 0.364 & 0.178 & $2.039 *$ \\
\hline 24 & Design team's experience & Desig. & 1 & & \\
\hline 25 & Project design complexity & Desig. & 1.104 & 0.252 & $4.377 * * *$ \\
\hline 26 & Mistakes/delays in producing design documents & Desig. & 0.901 & 0.28 & $3.214^{* * *}$ \\
\hline 27 & Ability to make clear and precise drawings & Desig. & 0.907 & 0.228 & $3.976 * * *$ \\
\hline 28 & Contractors experience & Contra. & 1 & & \\
\hline 29 & Site management & Contra. & 1.295 & 0.456 & $2.843^{*}$ \\
\hline 30 & Extend (Involvement) of subcontracting & Contra. & 1.173 & 0.465 & $2.523 *$ \\
\hline 31 & Contractor's cash flow & Contra. & 1.21 & 0.492 & $2.461 *$ \\
\hline 32 & Speed of information flow b/w owner \& contractor & Contra. & 2.205 & 0.646 & $3.41 * * *$ \\
\hline 33 & Knowledge of workers in the work & Contra. & 1.728 & 0.529 & $3.267 * *$ \\
\hline 34 & Relationship b/w owner \& contractor & Contra. & 1.283 & 0.522 & $2.457 *$ \\
\hline
\end{tabular}




\begin{tabular}{|l|l|l|l|l|l|}
\hline 35 & Use of advanced technology \& equipment's in construction & Contra. & 2.09 & 0.699 & $2.99^{* *}$ \\
\hline 36 & PM's competence & P. Mgr. & 1 & & \\
\hline 37 & PM's experience & P. Mgr. & 0.807 & 0.191 & $4.227^{* * *}$ \\
\hline 38 & PM's authority to take day to day decisions & P. Mgr. & 1.158 & 0.248 & $4.674^{* * *}$ \\
\hline 39 & PM's Technical capability & P. Mgr. & 0.921 & 0.225 & $4.096^{* * *}$ \\
\hline 40 & PM's leadership skills & P. Mgr. & 1.247 & 0.245 & $5.099^{* * *}$ \\
\hline 41 & Coordinating ability of PM with contractors & P. Mgr. & 1.558 & 0.298 & $5.23^{* * *}$ \\
\hline 42 & $\begin{array}{l}\text { PM's authority to take financial decisions, selecting key } \\
\text { team members }\end{array}$ & P. Mgr. & 1.044 & 0.244 & $4.272^{* * *}$ \\
\hline 43 & Coordinating ability of PM with top management & P. Mgr. & 1.532 & 0.294 & $5.202^{* * *}$ \\
\hline 44 & PM's confidence on the team members & P. Mgr. & 1.495 & 0.304 & $4.924^{* * *}$ \\
\hline 45 & Economic environment & Busi. & 1 & & \\
\hline 46 & Social environment & Busi. & 1.272 & 0.507 & $2.508^{*}$ \\
\hline 47 & Political environment & Busi. & 1.689 & 0.641 & $2.633^{* *}$ \\
\hline 48 & Commitment of all parties to the project & Busi. & 2.2 & 0.696 & $3.162^{*}$ \\
\hline 49 & Adequacy of funding & Busi. & 2.027 & 0.652 & $3.108^{* *}$ \\
\hline 50 & Technology availability & Busi. & 1.899 & 0.607 & $3.127^{* *}$ \\
\hline 51 & Human skill availability & Busi. & 1.13 & 0.41 & $2.757^{* *}$ \\
\hline
\end{tabular}

$* * * p \leq 0.001, * * p \leq 0.01, * p \leq 0.1$

Table 7. Factor categorized based on critical ratios

\begin{tabular}{|c|l|l|c|}
\hline Sl.no. & \multicolumn{1}{|c|}{ Success factor } & Related Factors & CR \\
\hline 1 & Coordinating ability of PM with contractors & P. Mngr. RF & 5.23 \\
\hline 2 & Coordinating ability of PM with top management & P. Mngr. RF & 5.202 \\
\hline 3 & PM's leadership skills & P. Mngr. RF & 5.099 \\
\hline 4 & PM's confidence on the teammembers & P. Mngr. RF & 4.924 \\
\hline 5 & PM's authority to take day to day decisions & P. Mngr. RF & 4.674 \\
\hline 6 & Project design complexity & Desig. RF & 4.377 \\
\hline 7 & PM's authority to take financial decisions, selecting key teammembers & P. Mngr. RF & 4.272 \\
\hline 8 & Timely bidding & Procu. RF & 4.229 \\
\hline 9 & PM's experience & P. Mngr. RF & 4.227 \\
\hline 10 & PM's Technical capability & P. Mngr. RF & 4.096 \\
\hline
\end{tabular}

The Project manager's ability to coordinate with contractors is the top most critical success factor with a criticality ratio of 5.23. Most of the factors are related to project manager. Project manager's coordination ability with the contractor as well as top management has highest importance, followed by his leadership skills and confidence in the team members. Seven factors categories were measured against the Criticality index and it was found that project manager related factors is most critical with a criticality ratio of 9.72 and contractor related factors with 8.65 criticality ratio.

\section{DISCUSSIONS AND CONCLUSION}

Reliability test is performed on all variables to ensure that the items measuring each variable belong to the same group and successfully measuring what they were intended to measure. Reliability test was also performed to test the internal consistency of scale used. The results (Table 7) shows that it can be concluded that the project manager has a major role in the project success followed by factors related to contractor and the client or the organization. Of ten CSF's (Pinto,1982) the eight of them are project manager related success factors. Out of nine success factors listed in the project manager category eight of them fall in top 10 CSF list. This study confirms that the project manager is the major key stakeholder in the project. The result confirms previous research studies [5]. Project manager should be experienced with a firm knowledge in the technical aspects of the project. To conclude the project manager must be a 
facilitator between all the participants involved in the project. The project manager must be an effective communicator with all the stakeholders in the project.

\section{LIMITATION OF THIS RESEARCH}

The survey carried out is in this company context only and the sample size was limited. However the findings of this study cannot be generalized as it needs the analyzing multiple projects to identify the critical success factor. By adding the delay factors in the questionnaire will give more insights to the project success.

\section{ACKNOWLEDGEMENTS}

The authors would like to thank Ms. Dona Joseph, PG Student, Manipal University, MIT Manipal, India for her effort in preparing this report.

\section{REFERENCES}

[1] A K Munns and B F Bjeirmi (1996), "The role of project management in achieving project success," International Journal of Project Management, Vol. 14, No. 2, pp 81-87.

[2] Akinsola, A. O., Potts, K. F., Ndekugri, I., and Harris, F. C., (1997) "Identification and evaluation of factors influencing variations on building projects,' International Journal Project Management, Vol. 15, No. 4, pp 263-267.

[3] Chan Wai Kuen, Suhaiza Zailani and Fernando, Y.(2009), "Critical factors influencing the project success amongst manufacturing companies in Malaysia," African Journal of Business Management, Vol. 3, No. 1, pp 16-27.

[4] Chua, D. K. H., Kog, Y. C., and Loh, P. K.(1999), "Critical success factors for different project objectives,' Journal of Construction Engineering Management, Vol. 125, No. 3, pp 142-150.

[5] Divakar K and Subramanian K. (2009), "Critical Success Factors in the Real-Time Monitoring of Construction Projects," Research Journal of Applied Sciences, Engineering and Technology, Vol. 1, No. 2, pp 35-39.

[6] Pinto, J. K. and Slevin, D. (1988), "Project Success: Definitions and measurement techniques," Project Management Journal, Sylva, Vol. 19, No. 1, pp 67-72.

[7] Jaselskis E. J., and Ashley, D. B. (1987), "Determinants of construction project success," Project Management Journal, Vol. 18, No. 2, pp 69-79.

[8] Jeffrey, S. R., J. J. Edward and P. L. Samuel, (1997), "Continuous assessment of project performance," Journal of construction Engineering Management, Vol. 123, No. 1, pp 64-71.

[9] John F Rockart, (1982), "The changing role of the information systems executive: A critical success factors perspective,” Sloan Management Review, Vol. 24, No. 1, Fall, pp. 3-13.

[10] Kumaraswamy M. M., and Chan, D. W. M, (1999), "Factors facilitating faster construction," Journal of Construction Management, Vol. 5, No. 2, pp 88-98.

[11] Liu, Anita M. M and Antony Walker, (1998), "Evaluation of project outcomes," Construction Management and Economics, Vol. 16, No. 2, pp 209-219.

[12] Meyer, A. D., Loch, C. H. and Pich, M.T. (2002), "Managing project uncertainty: from variation to chaos", MIT Sloan Management Review, Vol. 43, No. 2, pp 60-70.

[13] Muhammad Saqib, Rizwan U Farooqui and Sarosh H. Lodi, (2008), Assessment of Critical Success Factors for Construction Projects in Pakistan," Proceedings on 'Advancing and integrating construction education, research \& practice', (ICCIDC-I), International Conference held at Karachi, Pakistan, August 4-5.

[14] Joseph A. Gliem and Rosemary R. Glien (2003), Calculating, Interpreting, and Reporting Cronbach's Alpha Reliability Coefficient for Likert-Type Scales, Midwest Research Practice Conference in Adult, Continuing and Community Education, The Ohio State University, USA.

[15] Peter Morris and George H. Hough, (1987), The Anatomy of Major Projects: A Study of the Reality of Project Management, John Wiley \& Sons, NJ.

[16] Terry Cooke-Davies, (2002), "The real success factors in projects," International Journal of Project Management, Vol. 20, No. 3, pp 185-190.

[17] Walid Belassi and Oya Tukel, (1996) "A new framework for determining critical success/failure factors in projects,” International Journal of Project Management, Vol. 14, No. 3, pp 141-152. 
International Journal of Recent advances in Mechanical Engineering (IJMECH) Vol.3, No.2, May 2014

\section{Authors}

Mr. Potti Srinivasa Rao is an Assistant Professor (Senior Scale) in Department of Humanities and Management at Manipal University, Manipal Institute of Technology, Manipal. India. He has B.E. (Mechanical Engineering), M.E. (Industrial Engineering). His research area includes Engineering college quality assessment. He has published articles in the national journals and conferences. Mobile: $+91-9448843102$.

Prof. Shiva Prasad H C is a Professor in Department of Humanities and Management at Manipal University, Manipal Institute of Technology, Manipal. India. He has B.E. (Industrial Production Engineering), M.E.(Production Management) and Ph.D. (Organizational Behaviour). His areas of research interest include Performance, Emotional Competences, Knowledge Management, and Entrepreneurship. He has published articles in the international journals and conferences. He can be contacted at hcshipra@ gmail.com, Mobile: +91-9686122971.

Prof. Gopalkrishna B is a Professor in Department of Humanities and Management at Manipal University, Manipal Institute of Technology, Manipal. India. He has B.E. (Mechanical Engineering), M.E. (Engineering Management) and Ph.D. (Service Marketing). His areas of research interest include Marketing, risk analysis, Insurance and Value Engineering. He has published articles in the international journals and conferences.

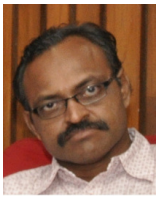

He can be contacted at bg_mit@yahoo.com, Mobile: +91-9980097242. 